\title{
Impact of Human Settlements on Diversity of Range Vegetation
}

\author{
Akash Jamil ${ }^{1} @$, Muhammad Zubair ${ }^{1, *}$, Syed Amir Manzoor ${ }^{1}$, Mamoona Wali Muhammad ${ }^{2}$, Ghulam Yasin ${ }^{1,3}{ }^{\circledR}$, \\ Shafeeq Ur Rahman ${ }^{4}\left(\mathbb{D}\right.$, Mashail Nasser Alzain ${ }^{5}$, Abdulaziz A. Alqarawi ${ }^{6}$ and Elsayed Fathi Abd_Allah ${ }^{6}$
}

1 Department of Forestry and Range Management, FAS \& T, Bahauddin Zakariya University Multan, Multan 60000, Pakistan; akashjamil2@live.com (A.J.); amir.kzd@gmail.com (S.A.M.); yasin_2486@yahoo.com (G.Y.)

2 Forest Education Division, Pakistan Forest Institute, Peshawar 25130, Pakistan; mamoonamuhammad313@gmail.com

3 Department of Forestry, Range and Wildlife Management, Faculty of Agriculture and Environment, The Islamia University, Bahawalpur 63100, Pakistan

4 Farmland Irrigation Research Institute, Chinese Academy of Agricultural Sciences, Xinxiang 453003, China; malikshafeeq1559@gmail.com

5 Department of Biology, College of Sciences, Princess Nourah Bint Abdulrahman University, Riyadh 11451, Saudi Arabia; mnalzain@pnu.edu.sa

6 Plant Production Department, College of Food and Agricultural Sciences, King Saud University, Riyadh 11451, Saudi Arabia; alqarawi@ksu.edu.sa (A.A.A.); eabdallah@ksu.edu.sa (E.F.A.)

* Correspondence: zubair.fast@bzu.edu.pk

check for

updates

Citation: Jamil, A.; Zubair, M.; Manzoor, S.A.; Wali Muhammad, M.; Yasin, G.; Ur Rahman, S.; Alzain, M.N.; Alqarawi, A.A.; Abd_Allah, E.F. Impact of Human Settlements on Diversity of Range Vegetation. Sustainability 2022, 14, 519. https:/ / doi.org/10.3390/su14010519

Academic Editors: Bryan A. Endress and Rainer W Bussmann

Received: 1 November 2021 Accepted: 30 December 2021

Published: 4 January 2022

Publisher's Note: MDPI stays neutral with regard to jurisdictional claims in published maps and institutional affiliations.

Copyright: (C) 2022 by the authors. Licensee MDPI, Basel, Switzerland. This article is an open access article distributed under the terms and conditions of the Creative Commons Attribution (CC BY) license (https:// creativecommons.org/licenses/by/ $4.0 /)$.

\begin{abstract}
The rapidly increasing population of human beings in semi-arid areas is often considered as a major factor of land degradation. Only a few studies have examined the dynamics of human settlements on the composition, diversity, structure and palatability of range vegetation in Southern Punjab Pakistan. The current study aims to assess whether the distance from settlements had any effect on the range vegetation's diversity and cover. In order to determine the impact of human settlements on the vegetation, the sampling area (Thal rangeland) was classified into three categories, i.e., Near (1-2 km from human communities), Away (2-4 km from human communities), and Far (4-6 km from human settlements). A total of 75 transects in all of the three sites were placed in the study sites. Along the transects, a quadrate of $1 \mathrm{~m}^{2}$ after every $10 \mathrm{~m}$ was randomly placed. The study site yielded floral diversity of a total of 29 species, representing 23 genera and belonging to 9 families. Results showed that the areas away from the human communities had higher species diversity (20), while the site near to human settlements depicted lower diversity (14). It was observed that, although the site near to communities had lower diversity, it depicted higher plant density, while the highest diversity along with the lowest plant density was observed in sites away from the communities. The study concluded that the diversity of range grasses, especially desirable species, was affected by distance to human settlements. These findings could be useful to detect flora changes, establish habitat protection priorities and improve efforts for conserving natural landscapes.
\end{abstract}

Keywords: range vegetation; diversity; palatable species; vegetation inventory; population gradient

\section{Introduction}

The rapidly increasing population of human beings is a key driver of land degradation and desertification all around the world. By the end of this decade, about $25 \%$ of the global population will be directly affected by land degradation [1]. Desertification in this era is mainly led either by climatic changes or rapidly spreading human settlements. As the human communities are settling in arid and semi-arid environments, activities such as over cutting of trees, over grazing, disposing of solid wastes, road construction and formation of settlements have become drivers in altering the natural ecosystem [2]. Transformed or lost natural habitats, changes in floristic composition, decreased diversity and alteration in vegetation structure are now commonly observed [3]. 
The spatial distribution pattern of plant communities and vegetation diversity in arid environments is mainly dependent upon three factors, i.e., anthropogenic disturbance, water availability and soil conditions. A small extent of disturbance in desert ecosystems has an enhanced effect on the vegetation structure and diversity [3]. This is due to the extreme temperatures, erratic rainfall and low fertility that make the recovery in these regions extremely slow. For the process of recovery to be smooth, the human impact on the natural environment must decrease. Various studies have shown human settlements to critically effect the biodiversity and characteristics of the vegetation communities in major desert ecosystems [4,5].

Over grazing is the most observed anthropogenic activity in arid and semi-arid rangelands. Frequent over grazing tends to alter vegetation composition and structure. Due to this activity, desired vegetative species are often replaced by undesired or toxic plant species [6]. Increased soil compaction, erosion and reduced soil carbon levels are also associated with heavy grazing [4]. Various studies in the desert ecosystems of Chile [7], Kuwait [8] and Egypt [9] have depicted livestock induced grazing as drastically effecting the vegetation quality, composition and cover. Research has shown that the most effected are the most frequently used rangeland areas [10]. Livestock congregations, usually near communities and watering points, generally have poor vegetation structure, composition and diversity due to regular trampling and heavy grazing [11].

Rangeland occupies more than 60\% of Pakistan's total land area. Rangelands in Pakistan are the largest source of land use, providing food and livelihood to countless landless poverty-stricken families [12]. The impacts of climate change are eminent in these ecosystems, as decreasing and erratic rainfall patterns coupled with over exploitative, stagnant and unsustainable management practices have taken these fragile rangelands to the brink of extensive degradation and desertification [13]. Thus, these once lush green grasslands are now facing decreased biodiversity and altered vegetation structure and floristic composition due to an unplanned population boom and poor range practices [14].

In the literature, there are many indirect measures, also known as proxies, for estimating the effects of grazing on rangeland vegetation [15-17]. Among these measures, distance from the communities, number of animal's excreta, number of burrows and distance from water bodies are normally used. However, the sustainability of these measures in various regions is rarely tested [18]. According to studies, distance from communities and grazing intensity are inversely proportional. Such patterns suggest transition zones or even thresholds that indicate irreversible parameter changes along a continuous gradient of grazing intensity [16]. As grazing intensity depends on a spatio-temporal pattern, foraging decisions and managerial interventions enhance or decrease the intensity of grazing along these areas [17]. In the past, this indicator has successfully given general information about the grazing intensity with respect to human settlements [19].

Knowledge regarding the floristic composition of a certain area is known as a prerequisite for any ecological, phyto-geographical and management practices [20]. Vegetation composition depicts the plant diversity of a certain area that could be dependent upon anthropogenic disturbances, over grazing and soil deterioration [21]. Identification of vegetation structure and composition along with an area's description can give information regarding local species, its growth periods, hardiness, growth of new species and effect of climatic and anthropogenic disturbances [22]. Various ecological and floristic investigation (vegetation analysis, species diversity and correlations between diverse edaphic factors) in different microhabitats of Egypt [23], Saudi Arabia [24], China [25] and Iran [26] were conducted. These studies were able to determine the status of current vegetation in the deserts and the effect of various proxies on the grazing resources of the rangelands. These studies have extreme importance in formulating the future policies of conservation and management plans.

Floristic composition analysis from grazing hotspots such as settlements, camps, rest areas or watering points is a much-used approach for determining the grazing intensity and its effect on the biodiversity and structure of vegetation $[20,27]$. This method is easy 
and quick in estimating the effect of various grazing intensities on vegetation and soil parameters. Though these proxies are frequently used in determining grazing intensity around the world, their applicability in measuring true grazing intensity on the subcontinent is still unchecked [28], as there are few studies that have described the behavior and activity of livestock change with the gradient of human settlements, water points or resting camps [29,30]. Thus, in order to assess the relationship and variability among the proxies of grazing intensity within a Pakistani context, this study is designed to examine the suitability of grazing intensity proxy across landscape properties.

The current study aims to determine the link between human settlements and diversity of range vegetation. The research assesses rangeland condition in areas near, away and far from human villages. The biodiversity of the area was determined using botanical composition, frequency, density and various biodiversity indices. Diversity of vegetation species in relation to closeness of human settlements was selected as an indicator for assessing grazing intensity by the livestock. The study is unique in its approach, as a new dimension of knowledge in terms of the role of distance from grazing communities influencing the diversity, abundance and distribution of range vegetation is added. The main objectives of this research were (a) to identify the forage diversity of this desert ecosystem, (b) to assess the link among vegetation diversity and human settlements and (c) to determine the floristic similarities near, away and far from human settlements.

\section{Materials and Methods}

\subsection{Study Site}

Located in southern Punjab, Pakistan, Thal is the third largest desert of the country (Figure 1). It covers about 2.5 million hectares having six major districts of Bhakkar, Mianwali, Layyah and a few parts of Jhang, Sargodha and Kushab. Thal is known to fall under the semi-arid to hyper arid climatic regions (rainfall $<200 \mathrm{~mm}$ ), with most rain occur during monsoon between June and August (400-800 mm). The temperatures in this part of the world are soaring hot, as the temperature can reach up to $45^{\circ} \mathrm{C}$ in the summer, and the winter is characterized by hot days and cold nights. The region falls under flat topography and the soils are moderately calcareous and have low organic matter content (about 0.4 percent).

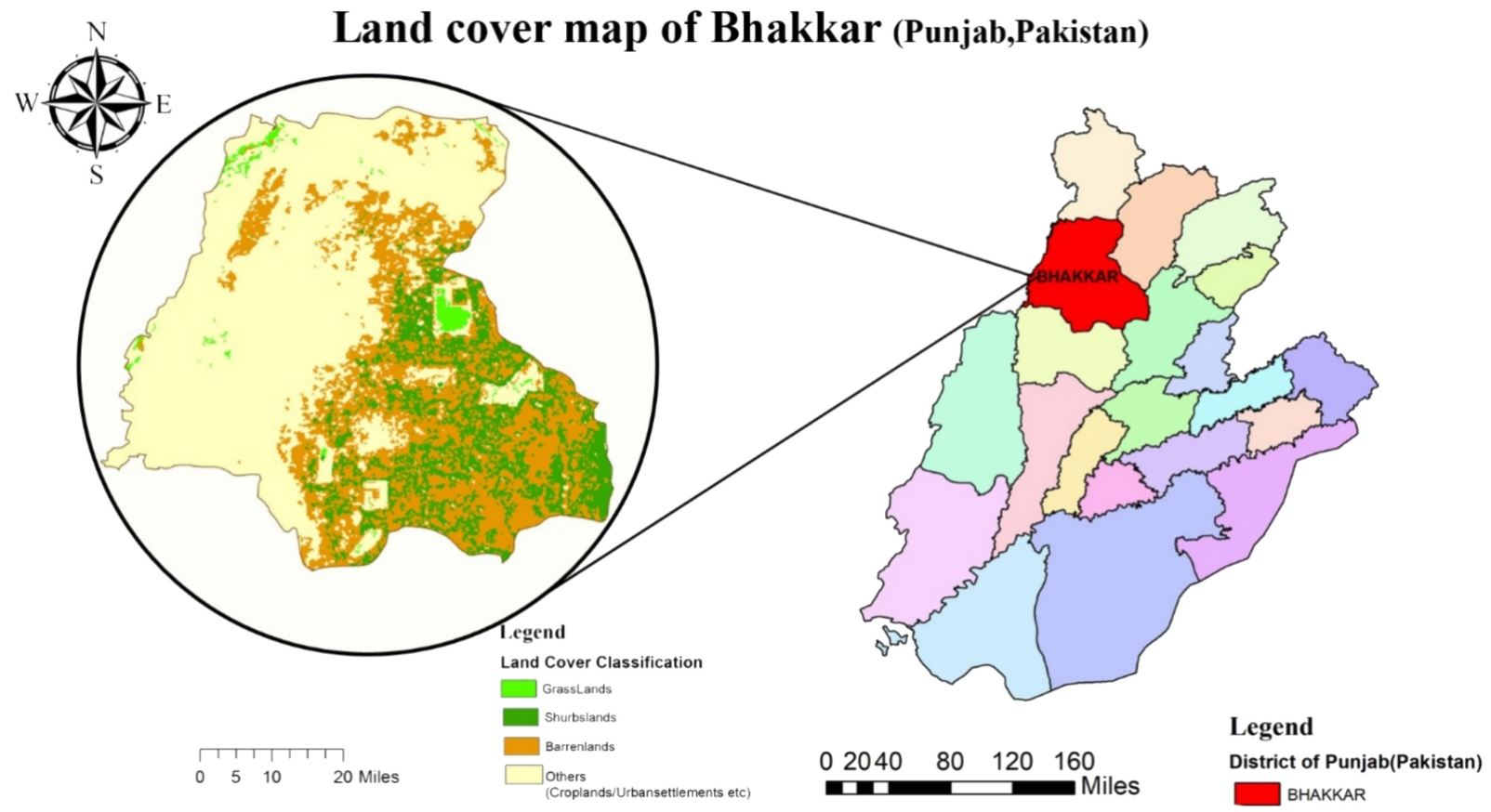

Figure 1. Map of the study area. 
About $32 \%$ of the total land in this region is classified as grazing land (Figure 1). These grazing resources are grouped into nine rakhs (range management units) controlled by the forest and range department of Punjab. Despite being extremely arid, various grasses, shrubs, herbs and tree species grow widely in order to sustain the livelihood of the pastoral communities dependent upon it for their livestock. This region has been used for centuries as a productive rangeland to produce livestock. The people in Thal heavily rely on livestock farming as a secure livelihood option.

The current study focused on three villages surrounding Rakh Khairaywala, along with the allocated grazing lands of each village. These villages were selected based on the presence of grazing land and existence of traditional herders. According to the Pakistan Bureau of Statistics, among these five villages, a total of 1062 households were resident and dependent upon available forage resources. Grazing practices involved year-round continuous grazing at set prices by the forest and range department.

\subsection{Sampling Design and Instruments}

The study aimed to determine the diversity of grazing vegetation among the gradient of human settlements in Rakh Khairaywala. Conventional techniques of vegetation inventory were employed for fulfilling the objective. For this purpose, the area was classified into three categories, i.e., Near (1-2 km from human communities), Away (2-4 km from human communities) and Far (4-6 km from human settlements). Several instruments were used to collect field data: a $1 \times 1 \mathrm{~m}$ quadrat, weight balance, global positioning system (GPS) navigation device, measuring tape, clipper, pegs and field notebook/range vegetation forms, map of the area and paper sacks.

\subsection{Data Collection}

Within each of the three key sites - Near, Away and Far from communities-25 $\times 100 \mathrm{~m}$ transects were set up at a distance of $100 \mathrm{~m}$ apart, making a total of 75 transects in all of the three sites. Sampling was conducted during the late monsoon period when the forage resources were at their peak. To cover all the vegetation characteristics and to determine range forage biodiversity, the quadrate method was used. Along the transect, after every $10 \mathrm{~m}$, a quadrate of $1 \mathrm{~m}^{2}$ was randomly placed. This method is useful in obtaining information about the species and its coverage in the targeted area. The vegetation inside the quadrate was taken out with the help of a clipper affixed at $2.5 \mathrm{~cm}$ starting from the base of the plant. The clipped sample was freshly weighed using a portable weight balance then placed in paper bags. These bags were then securely transported to the laboratory. These samples were then transferred into an oven that was dried for $70^{\circ} \mathrm{C}$ for $48 \mathrm{~h}$, unless a constant weight was achieved. The samples were than weighed again in a weighing balance for determining the biomass of the vegetation. The field identification of plants was carried out by the local grazers and the elders in the community, while the nomenclature of the plant species followed the global biodiversity information facility (gbif.org).

\subsection{Data Analysis}

To determine the effect of human settlements on the available forage, various biodiversity analyses were carried out among the selected sites. Primarily, the most basic quantitative analysis in the form of frequency $(F)$, density $(D)$ and vegetation abundance was performed using Curtis and McIntosh. Species distribution and their abundance were determined using Miller and Wiegert [31]. To assess the dominance of a species in each site, the important value index (IV) was calculated, while a species' richness, heterogeneity, evenness and dominance were estimated using Margalef, Shannon, Buzas and Gibson and Simpson indices, respectively [32-35]. Similarity in species composition among the human settlements interval was determined using the Jaccard coefficient model of similarity, utilizing the absence and presence of species as per [36]. Furthermore, the rank abundance curve was plotted to visualize species' richness and evenness. The rank abundance curve is useful as it incapacitates the inadequacies of biodiversity indices which are unable to 
display the relative part that different variables play in their calculation [37]. To display the efficacy of sampling, true species richness in a specific habitat and to compare species richness among various habitats on an equal basis, rarefaction curves were plotted [38].

\subsection{Statistical Analysis}

Biodiversity indices for range vegetation, abundance and species evenness were carried out using PAST software. Moreover, the Jaccard coefficient of similarity [39] was used to test the differences and similarities in species compositions along the distance from settlements.

\section{Results}

\subsection{Characteristics of the Flora}

The results from the vegetation survey exhibited somewhat scanty understory vegetation. Generally, a low biodiversity of floral species was observed due to harsh climatic conditions. The study site yielded a total of 29 species, representing 23 genera and belonging to 9 plant families. The current rangeland was open for herders to graze all year round. The vegetation recorded was mostly native to this region. Nearly $80 \%$ of the plants surveyed were herbaceous in nature. About $18 \%$ of the vegetation found were shrubs, while $2 \%$ of the plant species were found to be ephemerals. The rangelands surveyed depicted $90 \%$ of the vegetation to be used as a forage resource. The vegetation data were obtained along a distance gradient from human settlements (Near, Away and Far from communities). The results showed that the areas away from the human communities had higher species diversity (20) while the site near to human settlements depicted lower diversity (14). It was observed that, though the site near to communities had lower diversity, it depicted a higher number of individual plants, while the lowest number of individual plants was observed in sites Far from the communities.

\subsection{Family Distribution}

There was a total of nine plant families (Poaceae, Amaranthaceae, Apocynaceae, Tetradiclidaceae, Apiaceae, Cucurbitaceae, Asteraceae, Borginaceae and Cyperaceae) observed during the vegetation survey. Poaceae came out to be the most abundant and dense family in the range land, constituting more than 300 individuals. Another dominant family reported in the survey was Amaranthaceae, while the least dominant family observed in all of the three sites was Tetradiclidaceae. The important value index displayed that, in each of the three sites, the dominant species had no equal distribution.

\subsection{Near to Human Settlements}

Range vegetation depicted a few plant species, but the number of individuals in this site were considerable. This site had a higher number of unpalatable or toxic plant species. The palatable species were very few in this site, indicating the impact of higher grazing activities at this site. Though the number of species in this site was low, the number of individuals was comparatively high (Figure 2). The most dominant, highly palatable species in this site was Eleusine indica (L.) Gaertn. $(\mathrm{F}=37 \% \mathrm{D}=373)$ and Cenchrus ciliaris L. $(\mathrm{F}=25 \%$. $\mathrm{D}=101)$. These species had higher density in the site but were sparsely spread, depicting lesser diversity. The structure and composition of unpalatable species in this site was also similar but had more spread. The most dominant unpalatable species at the site were Aerva Javanica (Burm.fil.) Juss. $(\mathrm{F}=18 \% \mathrm{D}=64)$ and Kochia indica Wight ( $\mathrm{F}=12 \% \mathrm{D}=46$ ). Highly palatable and valuable forage species such as Launea residifolia (L.) Kuntze $(\mathrm{F}=2 \% \mathrm{D}=10)$, Salsola baryosma (Roem. and Schult.) Dandy $(\mathrm{F}=1 \% \mathrm{D}=2)$ and Cymbopogon jwarancusa (Jones) Schult. $(\mathrm{F}=6 \% \mathrm{D}=20)$ had lower representation in this site (Table 1). Generally, it was observed that the sites nearer to human settlements were more dominated by unpalatable species. The study depicted higher diversity and variation of unpalatable and toxic species that were not favorable for the animals (Figure 2). 


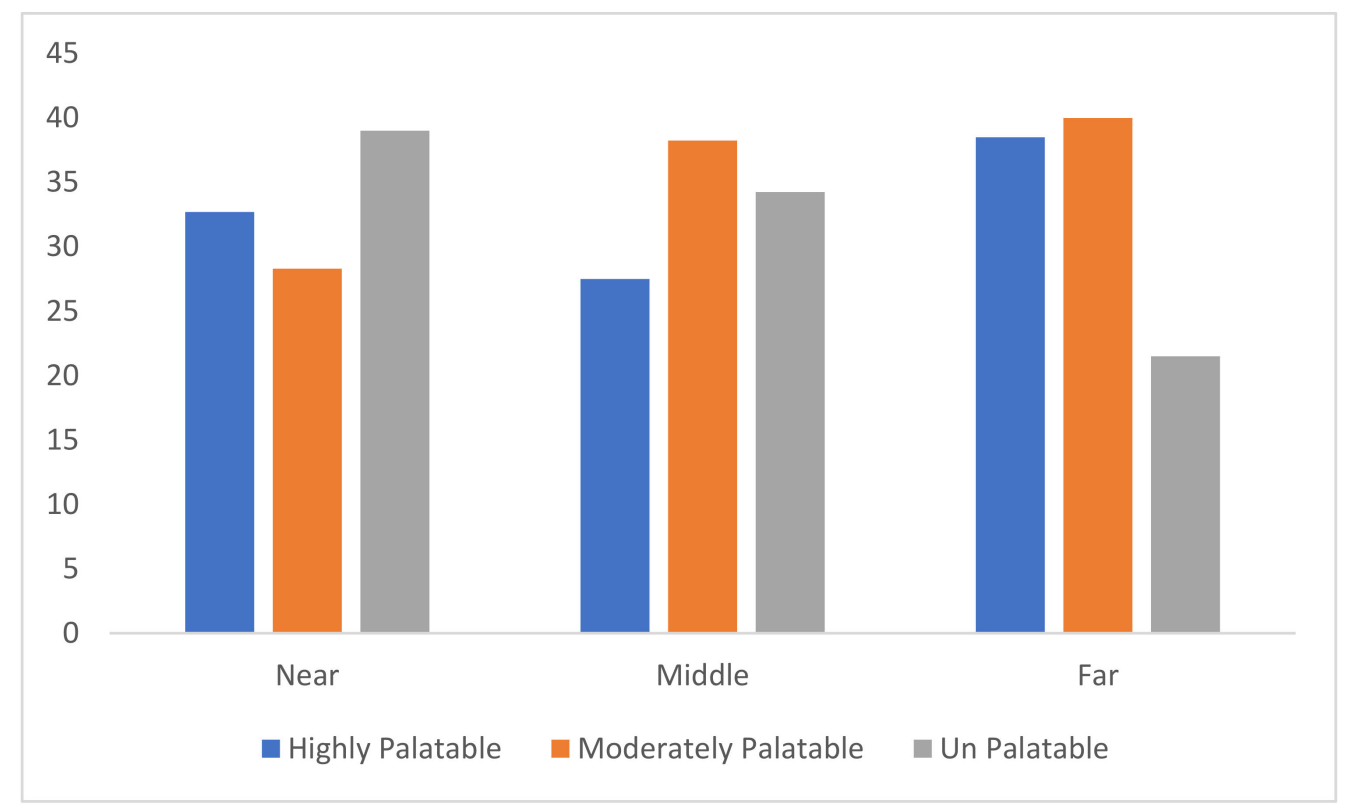

Figure 2. Status of palatable fodder in study sites.

Table 1. Species Importance Index Values for the site near to human settlements in Rakh Chikkan (R.F: Relative Frequency, R.D: Relative Density, R.C: Relative Cover, and I.V.I: Species Importance Value).

\begin{tabular}{|c|c|c|c|c|c|c|}
\hline Species & Family & Classification & R.F & R.D & R.C & I.V.I \\
\hline Eleusine indica (L.) Gaertn. & Poaceae & $\begin{array}{c}\text { Highly Palatable } \\
\text { Grass }\end{array}$ & 0.34965 & 0.608483 & 0.223048 & 1.181182 \\
\hline Cenchrus ciliaris L. & Poaceae & $\begin{array}{c}\text { Highly Palatable } \\
\text { Grass }\end{array}$ & 0.244755 & 0.164763 & 0.204461 & 0.61398 \\
\hline \multirow{5}{*}{$\begin{array}{c}\text { Aerva Javanica (Burm.fil.) Juss. } \\
\text { Periploca calophylla } \\
\text { (Wight) Falc. } \\
\text { Peganus harmala L. } \\
\text { Echinophora spinosa L. } \\
\text { Citrullus colocynthis (L.) } \\
\text { Schrader }\end{array}$} & Amaranthaceae & Unpalatable Shrub & 0.153846 & 0.104405 & 0.167286 & 0.425537 \\
\hline & Apocynaceae & Unpalatable Shrub & 0.041958 & 0.016313 & 0.011152 & 0.069424 \\
\hline & Tetradiclidaceae & Less Palatable herb & 0.020979 & 0.016313 & 0.107807 & 0.145099 \\
\hline & Apiaceae & Unpalatable shrub & 0.034965 & 0.011419 & 0.066914 & 0.113299 \\
\hline & Cucrbitaceae & $\begin{array}{l}\text { Palatable (only } \\
\text { fruits) }\end{array}$ & 0.013986 & 0.006525 & 0.037175 & 0.057686 \\
\hline \multirow{3}{*}{$\begin{array}{c}\text { Launaea resedifolia (L.) Kuntze } \\
\text { Heliotropium crispum Desf. } \\
\text { Cymbopogon jawrancusa } \\
\text { (Jones) Schult. }\end{array}$} & Asteraceae & Highly Palatable & 0.020979 & 0.017945 & 0.081784 & 0.120708 \\
\hline & Boraginaceae & Toxic Herb & 0.006993 & 0.003263 & 0.022305 & 0.03256 \\
\hline & Poaceae & Palatable Grass & 0.06993 & 0.032626 & 0.02974 & 0.132296 \\
\hline $\begin{array}{c}\text { Salsola baryosma (Roem. and } \\
\text { Schult.) Dandy }\end{array}$ & Amaranthaceae & $\begin{array}{l}\text { Highly Palatable } \\
\text { Shrub }\end{array}$ & 0.013986 & 0.003263 & 0.011152 & 0.028401 \\
\hline Kochia indica Wight & Amaranthaceae & Unpalatable shrub & 0.083916 & 0.058728 & 0.007435 & 0.150079 \\
\hline Phalaris minor Retz. & Poaceae & Less palatable grass & 0.013986 & 0.004894 & 0.02974 & 0.04862 \\
\hline
\end{tabular}

\subsection{Away from Human Settlements}

As compared to the site near to communities, this site was a little more diverse in terms of vegetative species. Moderately palatable species depicted more diversity, density and frequency as compared to the previous site. Unpalatable species also had representation, but they were not as dominant as in the site near to settlements, although the presence of highly palatable species both in terms of density and diversity was lower as compared to the site near human settlements. Similar to the first site, the dominant highly palatable species in this site was also Eleusine indica $(\mathrm{F}=35 \mathrm{D}=307)$, but the density of this species was a little lower. This site was rich in moderately palatable species; the most considerable among them were Sporobolus arabicus Boiss. $(\mathrm{F}=8 \% \mathrm{D}=30)$, Aristida funiculata Trin. and Rupr. ( $\mathrm{F}=7 \% \mathrm{D}=27)$, Cynodon dactylon (L.) Pers. $(\mathrm{F}=10 \% \mathrm{D}=43)$ and Phalaris minor $(\mathrm{F}=4 \% \mathrm{D}=10)$. Among the unpalatable species, Aerva Javanica $(\mathrm{F}=20 \% \mathrm{D}=47)$ and Periploca calophylla (Wight) Falc. $(\mathrm{F}=18 \% \mathrm{D}=41)$ had major representation, while toxic and unfavorable species such as Echinophora spinosa L., Calotropis Procera (Aiton) Dryand 
$(\mathrm{F}=1 \% \mathrm{D}=2)$ and Kochia indicia $(\mathrm{F}=17 \% \mathrm{D}=4)$ also had fair representation at this site (Table 2).

Table 2. Species Importance Index Values for the site Away from human settlements in Rakh Chikkan (R.F: relative frequency, R.D: relative density, R.C: Relative Cover, and I.V.I: Species Importance Value.

\begin{tabular}{|c|c|c|c|c|c|c|}
\hline Species & Family & Classification & R.F & R.D & R.C & I.V.I \\
\hline Cenchrus ciliaris L. & Poaceae & $\begin{array}{l}\text { Highly Palatable } \\
\text { grass }\end{array}$ & 0.333333 & 0.225166 & 0.225166 & 0.729732 \\
\hline Echinophora spinosa L. & Apiaceae & Unpalatable shrub & 0.007937 & 0.001656 & 0.001656 & 0.016441 \\
\hline $\begin{array}{c}\text { Cymbopogon schoenanthus (L.) } \\
\text { Spreng. }\end{array}$ & Poaceae & Palatable grass & 0.015873 & 0.006623 & 0.006623 & 0.036194 \\
\hline $\begin{array}{l}\text { Aerva Javanica (Burm.fil.) Juss. } \\
\text { Cynodon dactylon (L.) Pers. }\end{array}$ & $\begin{array}{l}\text { Amaranthaceae } \\
\text { Poaceae }\end{array}$ & $\begin{array}{l}\text { Unpalatable Shrub } \\
\text { Palatable forage }\end{array}$ & $\begin{array}{l}0.222222 \\
0.015873\end{array}$ & $\begin{array}{l}0.077815 \\
0.016556\end{array}$ & $\begin{array}{l}0.077815 \\
0.016556\end{array}$ & $\begin{array}{l}0.457571 \\
0.046128\end{array}$ \\
\hline $\begin{array}{l}\text { Periploca calophylla } \\
\text { (Wight) Falc. }\end{array}$ & Apocynaceae & Unpalatable Shrub & 0.103175 & 0.067881 & 0.067881 & 0.232699 \\
\hline $\begin{array}{l}\text { Cymbopogon jwarancusa } \\
\text { (Jones) Schult. }\end{array}$ & Poaceae & $\begin{array}{l}\text { Highly Palatable } \\
\text { forage }\end{array}$ & 0.119048 & 0.061258 & 0.061258 & 0.248799 \\
\hline Eleusine indica (L.) Gaertn. & Poaceae & $\begin{array}{l}\text { Highly Palatable } \\
\text { forage }\end{array}$ & 0.214286 & 0.506623 & 0.506623 & 0.878442 \\
\hline $\begin{array}{l}\text { Calotropis Procera } \\
\text { (Aiton) Dryand. }\end{array}$ & Apocynaceae & Toxic Shrub & 0.02381 & 0.003311 & 0.003311 & 0.03397 \\
\hline Kochia indica Wight & Amaranthaceae & Unpalatable & 0.02381 & 0.006623 & 0.006623 & 0.235911 \\
\hline Phalaris minor Retz. & Poaceae & $\begin{array}{l}\text { Less Palatable } \\
\text { forage }\end{array}$ & 0.015873 & 0.003311 & 0.003311 & 0.067129 \\
\hline $\begin{array}{l}\text { Citrullus colocynthis (L.) } \\
\text { Schrader }\end{array}$ & Cucurbitaceae & $\begin{array}{l}\text { Palatable (only } \\
\text { fruits) }\end{array}$ & 0.015873 & 0.006623 & 0.006623 & 0.056742 \\
\hline Sporobolus arabicus Boiss & Poaceae & Palatable & 0.047619 & 0.024834 & 0.024834 & 0.120399 \\
\hline $\begin{array}{c}\text { Aristida funicula Trin. and } \\
\text { Rupr. }\end{array}$ & Poaceae & Palatable & 0.071429 & 0.033113 & 0.033113 & 0.159336 \\
\hline $\begin{array}{l}\text { Dichanthium annulatum } \\
\text { (Forssk.) Stapf }\end{array}$ & Poaceae & $\begin{array}{l}\text { Highly Palatable } \\
\text { forage }\end{array}$ & 0.02381 & 0.006623 & 0.006623 & 0.057829 \\
\hline
\end{tabular}

\subsection{Far from Human Settlements}

The site far from human communities was most diverse in terms of plant species, but the density of these species was the lowest as compared to the other sites (Figure 2). An increased number of species of highly palatable fodder was observed in the site. The most dominant were Elusine indica $(\mathrm{F}=14 \% \mathrm{D}=108)$ and Cymbopogon jwarancusa $(\mathrm{F}=12 \% \mathrm{D}=50)$, while Cenchrus ciliaris ( $\mathrm{F}=3 \% \mathrm{D}=12)$, Salsola baryosma $(\mathrm{F}=1 \% \mathrm{D}=3)$, Suaeda fruticosa (L.) Forssk. ( $F=1 \% D=2)$, Cymbopogon schoenanthus (L.) Spreng. ( $F=4 \% D=12)$ and Themeda triandra Forssk. $(\mathrm{F}=3 \% \mathrm{D}=10)$ had a minimal spread and lower individual numbers in the sites far from human communities. This site had more diverse palatable vegetation, but their spread and individual numbers were quite low as compared to other sites (Table 3). The moderately palatable species also had higher diversity but lower density. Among them, the most notable were Launaea resedifolia $(\mathrm{F}=7 \% \mathrm{D}=15)$, Panicum coloratum $\mathrm{L}$. $(\mathrm{F}=8 \% \mathrm{D}=10)$, Cynodon dactylon $(\mathrm{F}=18 \% \mathrm{D}=20)$ and Leptadenia pyrotechnica (Forssk.) Decne. $(\mathrm{F}=8 \% \mathrm{D}=14)$. Unpalatable species displayed a lower diversity far from human settlements. In this site, only a few unpalatable species dominated the grazing landscape, as they had higher density and frequency. Unpalatable species such as Aerva Javanica ( $\mathrm{F}=30 \%$ $\mathrm{D}=81)$, Periploca calophylla $(\mathrm{F}=18 \% \mathrm{D}=76)$ and Kochia indica $(\mathrm{F}=20 \% \mathrm{D}=65)$ dominated the grazing landscape (Table 3 ). 
Table 3. Species Importance Index Values for the site Far from human settlements in Rakh Chikkan

(R.F: relative frequency, R.D: relative density, R.C: Relative Cover, and I.V.I: Species Importance Value.

\begin{tabular}{|c|c|c|c|c|c|c|}
\hline Species & Family & Classification & R.F & R.D & R.C & I.V.I \\
\hline Cenchrus ciliaris L. & Poaceae & $\begin{array}{l}\text { Highly palatable } \\
\text { grass }\end{array}$ & 0.0390625 & 0.000154703 & 0.066225166 & 0.113255 \\
\hline $\begin{array}{c}\text { Cymbopogon jwarancusa (Jones) } \\
\text { Schult. }\end{array}$ & Poaceae & $\begin{array}{l}\text { Highly Palatable } \\
\text { grass }\end{array}$ & 0.0390625 & 0.000438325 & 0.152317881 & 0.285569 \\
\hline Eleusine indica (L.) Gaertn. & Poaceae & $\begin{array}{l}\text { Highly Palatable } \\
\text { grass }\end{array}$ & 0.0390625 & 0.000412541 & 0.139072848 & 0.264485 \\
\hline $\begin{array}{c}\text { Salsola baryosma (Roem. and } \\
\text { Schult.) Dandy }\end{array}$ & Amaranthaceae & $\begin{array}{l}\text { Highly Palatable } \\
\text { Herb }\end{array}$ & 0.0390625 & $7.73515 \times 10^{-5}$ & 0.013245033 & 0.03676 \\
\hline Aerva Javanica (Burm.fil.) Juss. & Amaranthaceae & Unpalatable Shrub & 0.0390625 & 0.000902434 & 0.225165563 & 0.499505 \\
\hline Periploca calophylla (Wight) Falc. & Apocynaceae & Unpalatable shrub & 0.0390625 & 0.000464109 & 0.139072848 & 0.280162 \\
\hline $\begin{array}{l}\text { Leptadenia pyrotechnica } \\
\text { (Forssk.) Decne. }\end{array}$ & Apocynaceae & Palatable Shrub & 0.0390625 & 0.000128919 & 0.086092715 & 0.125284 \\
\hline Aristida depressa Retz. & Poaceae & $\begin{array}{l}\text { Less Palatable } \\
\text { grass }\end{array}$ & 0.0390625 & $5.15677 \times 10^{-5}$ & 0.026490066 & 0.042167 \\
\hline Phalaris minor Retz & Poaceae & $\begin{array}{l}\text { Less Palatable } \\
\text { grass }\end{array}$ & 0.0390625 & $7.73515 \times 10^{-5}$ & 0.01986755 & 0.043382 \\
\hline Suaeda fruticosa (L.) Forssk. & Amaranthaceae & $\begin{array}{l}\text { Highly Palatable } \\
\text { Herb }\end{array}$ & 0.0390625 & $5.15677 \times 10^{-5}$ & 0.013245033 & 0.028922 \\
\hline Panicum coloratum L. & Poaceae & Palatable Herb & 0.0390625 & $2.57838 \times 10^{-5}$ & 0.006622517 & 0.014461 \\
\hline Launaea resedifolia (L.) Kuntze & Asteraceae & Less Palatable herb & 0.0390625 & $2.57838 \times 10^{-5}$ & 0.006622517 & 0.014461 \\
\hline Kochia indica Wight & Amaranthaceae & Unpalatable herb & 0.0390625 & $7.73515 \times 10^{-5}$ & 0.013245033 & 0.03676 \\
\hline $\begin{array}{c}\text { Cymbopogon schoenanthus (L.) } \\
\text { Spreng. }\end{array}$ & Poaceae & $\begin{array}{l}\text { Highly Palatable } \\
\text { herb }\end{array}$ & 0.0390625 & 0.000257838 & 0.079470199 & 0.157853 \\
\hline Eragrostis minor Host & Poaceae & Less Palatable & 0.0390625 & 0.000438325 & 0.092715232 & 0.225966 \\
\hline $\begin{array}{l}\text { Cenchrus pennisetiformis Hochst. } \\
\text { and Steud. }\end{array}$ & Poaceae & Highly Palatable & 0.0390625 & 0.000289 & 0.099337748 & 0.256103 \\
\hline Saccharum spontaneum L. & poaceae & Unpalatable & 0.0390625 & 0.0002987 & 0.072847682 & 0.135554 \\
\hline Themeda triandra Forssk & Poaceae & Highly Palatable & 0.0390625 & 0.0001987 & 0.059602649 & 0.083118 \\
\hline Cyperus alopecuroides Rotbb & Cyperaceae & Less Palatable & 0.0390625 & 0.0000654 & 0.066225166 & 0.105417 \\
\hline Cynodon dactylon (L.) Pers & Poaceae & Palatable & 0.0390625 & 0.0000263 & 0.092715232 & 0.16326 \\
\hline
\end{tabular}

\subsection{Biodiversity and Similarity Cluster Analyses}

There was a considerable difference in terms of vegetation diversity among the sites Near, Away and Far from the herders' communities. Various diversity indices were utilized for determining species diversity among the selected sites (Table 3). These indices are important in assessing different concepts of species richness, diversity, dominance and evenness. Our results depicted sites far from human settlements as having the most diverse vegetation in the rangeland. According to the results, the Shannon index in the far site was observed to have a comparatively higher value as compared to other sites. The higher Shannon value depicts the community as having higher diversity, incorporating maximum richness and evenness (Table 4). The site near to the herders' communities had the minimum Shannon diversity value. This site as compared to other sites had low diversity and species richness. For measuring dominance and abundance of the species, the Simpson index was utilized. It was observed that the site far from the human communities contained more dominant range vegetation. Similarly, the Simpson index displayed a minimum value in the site near to human settlements. The Menhinick and Buzas and Gibson index showed that the site away from communities had more richness and was comparatively more even than the other sites (Table 4).

Table 4. The average amount of indices and their comparisons in different sites.

\begin{tabular}{cccc}
\hline \multirow{2}{*}{ Indices } & \multicolumn{3}{c}{ Sites } \\
\cline { 2 - 4 } & Near to Community & Away to Community & Far from Community \\
\hline Shannon H & 1.605 & 1.528 & 2.009 \\
Simpson_1-D & 0.6365 & 0.6776 & 0.8066 \\
Menhinick & 0.8224 & 0.5697 & 0.9087 \\
(Spp Richness) & 0.2371 & 0.3291 & 0.4659 \\
Buzas and & & & \\
Gibson's evenness & &
\end{tabular}


The study carried out a cluster analysis on the density of the vegetation in each site to observe the relationships among species. By using this method, we can generally classify a community's sample data by displaying similarity among species in specific sites. The dendrogram representing the species density was drawn using cluster analysis by using the unweighted-pair group method with arithmetic mean (UOGMA). Bray-Curtis similarity distance was selected as the criteria for cluster combination. The results showed some similarity among various sites selected for the study. The composition of the various vegetation species at the site near to communities and in the site away from communities displayed a very similar relationship, having a value of 0.825 . This specifies that there is $82 \%$ similarity of species composition between site 1 and site 2 (Figure 3 ). These results indicate similar grazing and pattern in these areas, while site 3 had little similarity with the rest of the sites. This explains various species that were present at this site and were absent in the other two sites. This clustering of similarity among the three sites explains why site 1 and 2 had more degradation of vegetation and many species were being grazed at higher rates.

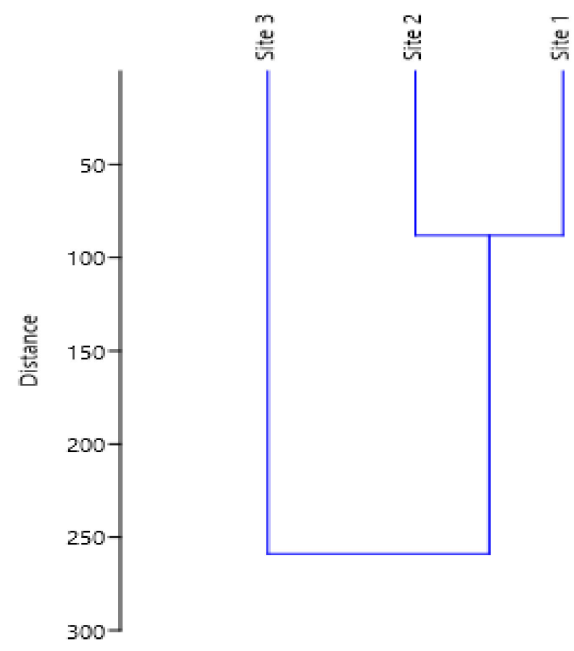

Figure 3. Cluster analysis displaying similarity of species among study sites (Site 1 = Near Table, Site 2 = Away from human settlements, Site 3 = Far from human settlements).

\subsection{Rank Abundance Curve and Rarefaction Curves}

Rank abundance curves are commonly plotted for displaying species' richness, abundance and evenness. In this plot, the $X$ axis depicts the rank of species in terms of their abundance, while the $Y$ axis shows the abundance of the species measured on a log scale (Figure 4). The figure shows the abundance, evenness and richness data from sites Near, Away and Far from human settlements in Thal rangeland. According to the results, the site near to communities depicts a steep slope. It shows the site's low evenness, having few dominant species occupying the area. The steep slope at the start displays higher relative abundance of few species, but a long tail represents quite a few rare species having low species frequency, density and abundance. The site away from the human settlements showed low evenness, as the slope is moderate. The abundance in this site was low but, comparatively, a higher diversity was observed over previous site. The site away from settlements was the most even, having an equal representation of species. This site had the most diverse vegetation, and the abundance of species was relatively distributed across this area. At the start, the slope was moderate at the away site, and then later on the slope became stable, depicting a higher dominance value of species with the terminal slope representing a few rare species in low abundance. Overall, the results display that the region has lower values of plant species coverage, that were mostly the functional equivalents of the dominant species but could differ with environmental requirements and tolerances. 


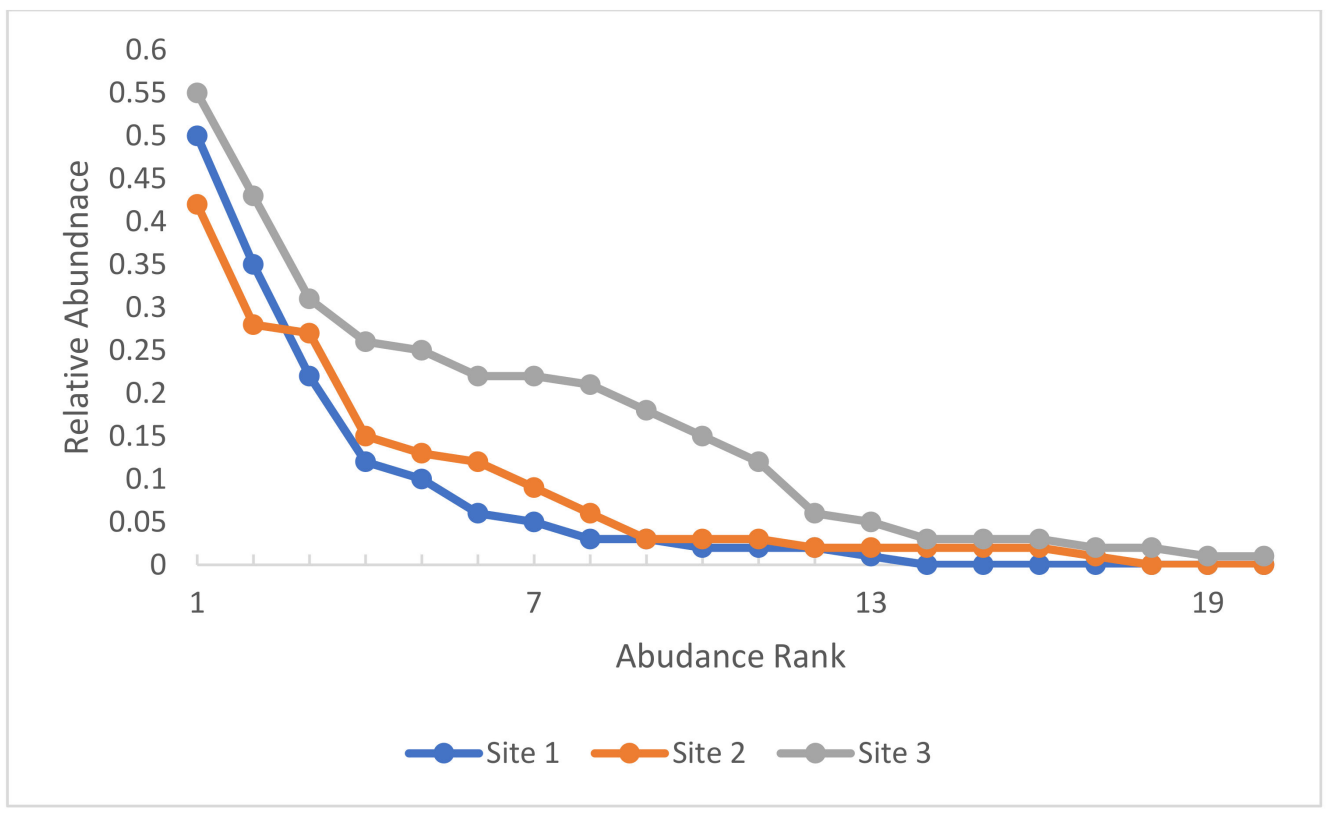

Figure 4. Rank abundance curve of the species observed in the study site (Site $1=$ Near to human settlements, Site 2 = Away from human settlements, Site 3 = Far from human settlements).

This study utilized individual rarefaction curves to evaluate the sampling effort. Rarefaction curves are important in describing the appropriate number of samples required for diversity analysis in a community. A plotted rarefaction curve describes species or taxa on the $X$ axis while the $Y$ axis represents the number of specimens or individuals found in the site (Figure 5). Usually, for curves in a rarefaction plot, if the curves keep rising steeply, this shows that the sampling effort was not sufficient. However, in the current study, the rarefaction plot shows the curves to rise steeply at first and then straighten horizontally. The curves in almost every site reached asymptote after rapidly moving upward, showing a good sampling effort. These results depict that there was an appropriate sampling effort undertaken in the targeted sites of the rangeland.

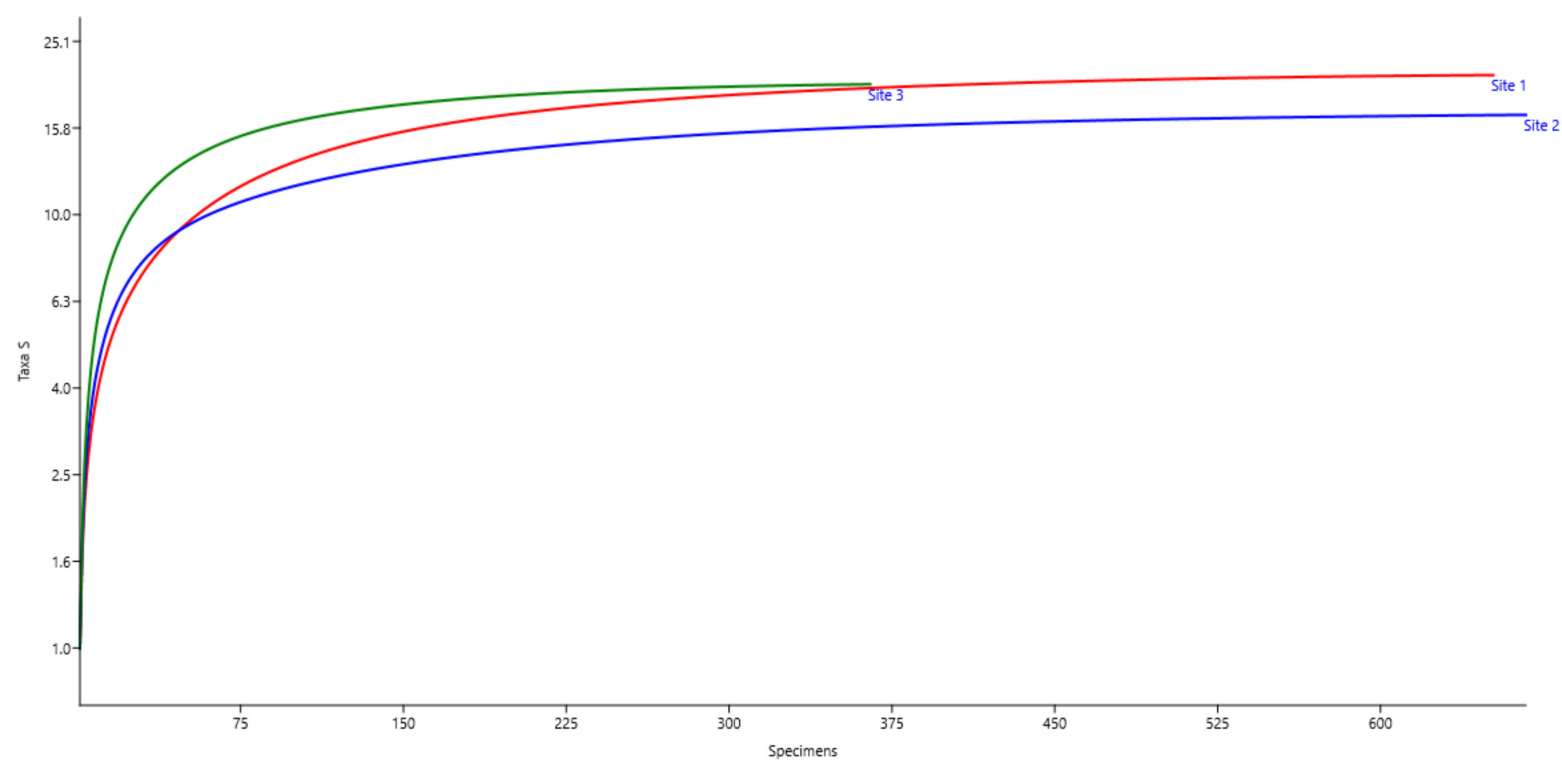

Figure 5. Rarefaction curve of the species observed in the study sites (Site $1=$ Near to human settlements, Site 2 = Away from human settlements, Site 3 = Far from human settlements). 


\section{Discussion}

The results depict the clear impact of human settlements on the diversity and cover of grazing vegetation present in the current rangeland. The sites near to human settlements displayed the lowest diversity, while the sites away from settlements had the highest diversity of grazing vegetation. Our results further advance the fact that the composition and structure of range vegetation varies with distance from human communities present in the rangelands. The current research is a baseline for monitoring changes in status and trends in range vegetation in relation to human settlements. The results obtained provide indicators of the vegetation's health and diversity in relation to distance from the grazing community.

Overall, the vegetation analysis at the various study sites depicted that most of the recorded plants were associated with four families, Poaceae and Amaranthaceae being the most dominant, followed by Asteraceae and Cucurbitaceae. Similar trends are normally observed in arid environments where members of only a few families dominate [3]. In the current study among a total of nine families, about five of them were only represented by a single species per family. This is consistent with various studies that have noted this common feature of desert vegetation, often considered as a signal of species adaptation in xeric conditions [40-42].

Most of the range species obtained from the survey had significant grazing value. The most palatable species came from those sites far from human settlements, while unpalatable species were more dominant in sites near and away from grazing communities. These results are in accordance with Angassa [43], who suggests that most grasses favored by livestock are usually decreaser species and thus are prone to grazing. A decreased number and diversity of palatable plants was observed in sites near and away from grazing communities. This demonstrates that increased grazing pressure affects the density of palatable plants, compelling the livestock to feed on species with minimal nutritional value [44]. The sites near and away from human settlements had dominant growth and cover of invasive and unpalatable plants. Vigorous growth of this vegetation often suppresses palatable species near villages and the piosphere [45]. Similar results were reported by Hoshino et al. [46], in which it was suggested that species composition is subject to change along the grazing gradient which is characterized by changes in vegetation cover structure and density of species. Our results are consistent with studies conducted in Botswana, which revealed that continuous grazing near grazing tents and pyrospheres led to diminished populations and diversity of favorable plant species [47].

At the current study sites, E. indica and C. ciliaris showed themselves to be the most resistant to heavy grazing. These species displayed the highest frequency in the sites near and away from human settlements. Many studies conclude that, in most arid rangelands, there are a few key grazing species that have significant potential to withstand heavy grazing. Our findings corroborate with [48], where similar species such as C. ciliaris and C. dactylon were most dominant near penning tents and piospheres. Further, these species are found to be extremely tolerant to fire and are adaptable to various edaphic and climatic conditions. In addition, these species are also found to be more resistant to flooding and salinity [49].

Vegetation species' diversity, richness and evenness in the Thal rangeland were observed to be higher in sites far from human settlements. This could be caused by significant trampling and defoliation in sites near and away from human population, which would lead to lower diversity and richness $[3,19]$. Further, a study conducted in a similar environment revealed lower species cover and stunted plant growth and development in sites near to penning tents and near water bodies. The increased trampling effect in such populated areas is known to slow down plant regeneration, thus affecting the species diversity and evenness [50,51]. Furthermore, increased hoof action is also known to cause soil compaction, therefore deterring water infiltration and thus leading to low plant growth Increased diversity in sites far from human settlements means moderate herbivory that leads to higher plant diversity [52]. Our results are in accordance with a similar study 
conducted in the arid rangelands of Kenya. It was observed that, as the intensity of grazing decreased, the diversity of vegetation increased. A study conducted in Nama-Karoo rangelands revealed twice as many species at sites near human and animal populations as compared to sites far from human population [53]. It is an established fact that the sites having higher degradation are usually dominated by one or two species, while the sites having lower degradation depict higher diversity [54]. These results corroborate with the current study, as the sites near to human populations were dominated by a single species making up most of the individual plants, while the sites away from population had more variety in terms of grazing species.

Similar to biodiversity indices, the abundance as depicted by a rank abundance curve displayed a higher abundance of species in sites away from human settlements. These results depict that anthropogenic activities in these rangelands degrade the lands and increase poverty. Many studies have shown that cutting trees, medicinal plant harvesting and keeping livestock in kraals near homes all become major causes of over exploitation of range resources [55-57], leading towards decreased plant cover, lower diversity and increased bare soil patches. These findings were based on an appropriate number of samples, as demonstrated by the rarefaction curves. These curves are mostly used in diversity datasets to avoid the pitfalls and limitations which often are experienced during quantifying and comparing taxon richness and diversity [58].

\section{Conclusions}

This study concluded that the diversity of range grasses, especially desirable species, had a clear link with distance to human settlements. Gradient distance depicted a stark influence on grazing species around the settlements of the grazers. While the areas near to grazing communities did depict subsequent vegetation cover, the diversity, specifically of desirable species, was low. The vegetation gradient was reduced along the settlement gradient, but the diversity of grasses, specifically of palatable species, seemed to increase. This points towards the anthropogenic disturbance that causes changes in the composition and structure of the grazing vegetation in these rangelands. Sites near to human settlements proved to be highly encroached on and degraded.

These sites near to human settlements were dominated by only a few species, had an increased number of undesirable and unpalatable species, showed poor regeneration and a lower species diversity was recorded, all of which pose concerns. Suitable measures should be taken to reduce anthropogenic pressure, especially in sites near to grazing communities. Appropriate conservation and management plans should be incorporated by the forestry and range departments to save biodiversity and create a sustainable forage availability. The recovery of plants, specifically in arid ecosystems, may take 60-250 years, while the period required for the whole ecosystem to recover is more than 2500 years. It is due to the sensitivity of arid habitats to disturbance that they are such slow in recovering naturally. In this context drastically altered habitats responsibility is upon the institutions dedicated for preserving these areas. As it is crucial to protect these valuable forage resource for sustaining the livelihood dependent upon it. In this scenario, our findings could be useful to detect flora changes, establish habitat protection priorities, and improve efforts for conserving natural landscapes.

Author Contributions: Conceptualization, Formal analysis, Writing—Original Draft Preparation: A.J. and M.Z.; Resources and data curation: S.A.M. and M.W.M.; Writing-Review and Editing, Supervision: G.Y. and S.U.R.; Writing—Review and Editing, Visualization, Funding Acquisition: M.N.A., A.A.A. and E.F.A. All authors have read and agreed to the published version of the manuscript.

Funding: The authors would like to extend their sincere appreciation to the Researchers Supporting Project Number (RSP-2021/134), King Saud University, Riyadh, Saudi Arabia.

Institutional Review Board Statement: Not applicable.

Informed Consent Statement: Not applicable. 


\section{Data Availability Statement: Not applicable.}

Acknowledgments: The authors would like to extend their sincere appreciation to Punjab Forest Department, Punjab in extending their cooperation in field work. The authors would like to extend their sincere appreciation to the Researchers Supporting Project Number (RSP-2021/134), King Saud University, Riyadh, Saudi Arabia.

Conflicts of Interest: The authors declare no conflict of interest.

\section{References}

1. Kimani, C. Impact of Human Population on Land Degradation. a Critical Literature Review. J. Environ. 2021, 1, 1-14. [CrossRef]

2. Mirzaev, B.; Mamatov, F.; Ergashev, I.; Islomov, Y.; Toshtemirov, B.; Tursunov, O. Restoring degraded rangelands in Uzbekistan. Procedia Environ. Sci. Eng. Manag. 2019, 6, 395-404.

3. Hussein, E.; El-Ghani, M.A.; Hamdy, R.; Shalabi, L. Do Anthropogenic Activities Affect Floristic Diversity and Vegetation Structure More Than Natural Soil Properties in Hyper-Arid Desert Environments? Diversity 2021, 13, 157. [CrossRef]

4. Wang, Z.; Wang, C.; Jiang, Z.; Hu, T.; Han, W.; Zhang, C.; Jin, J.; Wei, K.; Zhao, J.; Wang, X. Relationship between Rural Settlements' Plant Communities and Environmental Factors in Hilly Area of Southeast China. Sustainability 2020, 12, 2771. [CrossRef]

5. Ruvuga, P.R.; Wredle, E.; Nyberg, G.; Hussein, R.A.; Masao, C.A.; Selemani, I.S.; Sangeda, A.Z.; Kronqvist, C. Evaluation of rangeland condition in miombo woodlands in eastern Tanzania in relation to season and distance from settlements. J. Environ. Manag. 2021, 290, 112635. [CrossRef]

6. Mahmoudi, S.; Khoramivafa, M.; Hadidi, M.; Jalilian, N.; Bagheri, A. Overgrazing is a Critical Factor Affecting Plant Diversity in Nowa-Mountain Rangeland, West of Iran. J. Rangel. Sci. 2021, 11, 141-150.

7. Meserve, P.L.; Gómez-González, S.; Kelt, D.A. The Chilean Matorral: Characteristics, Biogeography, and Disturbance. In Encyclopedia of the World's Biomes; Elsevier Academic Press: Amsterdam, The Netherlands, 2020; pp. 594-601. [CrossRef]

8. Al-Shehabi, Y.; Murphy, K. Flora richness as an indicator of desert habitat quality in Kuwait. J. Threat. Taxa 2017, 9, 9777. [CrossRef]

9. Shaltout, K.; Eid, E.; Al-Sodany, Y.; Heneidy, S.; Shaltout, S.; El-Masry, S. Effect of Protection of Mountainous Vegetation against Over-Grazing and Over-Cutting in South Sinai, Egypt. Diversity 2021, 13, 113. [CrossRef]

10. Selemani, I.S. Indigenous knowledge and rangelands' biodiversity conservation in Tanzania: Success and failure. Biodivers. Conserv. 2020, 29, 3863-3876. [CrossRef]

11. Jawuoro, S.O.; Koech, O.K.; Karuku, G.N.; Mbau, J.S. Plant species composition and diversity depending on piospheres and seasonality in the southern rangelands of Kenya. Ecol. Process. 2017, 6, 515. [CrossRef]

12. Mansoor, M.; Jamil, M.; Anwar, F.; Awan, A.A.; Muhammad, S. Review A Review on Rangeland Management in Pakistan, Bottlenecks and Recommendations. Pak. J. Sci. Ind. Res. Ser. B Biol. Sci. 2018, 61, 115-120. [CrossRef]

13. Polley, H.W.; Bailey, D.W.; Nowak, R.S.; Stafford-Smith, M. Ecological Consequences of Climate Change on Rangelands. In Rangeland Systems; Springer International Publishing: Cham, Switzerland, 2017; pp. 229-260.

14. Ahmad, D.; Afzal, M. Impact of climate change on pastoralists' resilience and sustainable mitigation in Punjab, Pakistan. Environ. Dev. Sustain. 2021, 23, 11406-11426. [CrossRef]

15. Dorji, T.; Fox, J.L.; Richard, C.; Dhondup, K. An Assessment of Nonequilibrium Dynamics in Rangelands of the Aru Basin, Northwest Tibet, China. Rangel. Ecol. Manag. 2010, 63, 426-434. [CrossRef]

16. Tarhouni, M.; Ben Salem, F.; Belgacem, A.O.; Neffati, M. Acceptability of plant species along grazing gradients around watering points in Tunisian arid zone. Flora-Morphol. Distrib. Funct. Ecol. Plants 2010, 205, 454-461. [CrossRef]

17. Manthey, M.; Peper, J. Estimation of grazing intensity along grazing gradients-The bias of nonlinearity. J. Arid Environ. 2010, 74, 1351-1354. [CrossRef]

18. Dorji, T.; Totland, Ø.; Moe, S.R. Are Droppings, Distance from Pastoralist Camps, and Pika Burrows Good Proxies for Local Grazing Pressure? Rangel. Ecol. Manag. 2013, 66, 26-33. [CrossRef]

19. Wang, L.; Delgado-Baquerizo, M.; Zhao, X.; Zhang, M.; Song, Y.; Cai, J.; Chang, Q.; Li, Z.; Chen, Y.; Liu, C.; et al. Livestock overgrazing disrupts the positive associations between soil biodiversity and nitrogen availability. Funct. Ecol. 2020, 34, 1713-1720. [CrossRef]

20. Rafay, M.; Abdullah, M.; Hussain, T.; Ruby, T. Floristic composition of grass species in the degrading range lands of Cholistan desert. World Appl. Sci. J. 2013, 28, 2172-2176. [CrossRef]

21. Sparrow, B.D.; Foulkes, J.N.; Wardle, G.M.; Leitch, E.J.; Caddy-Retalic, S.; van Leeuwen, S.J.; Tokmakoff, A.; Thurgate, N.Y.; Guerin, G.R.; Lowe, A.J. A Vegetation and Soil Survey Method for Surveillance Monitoring of Rangeland Environments. Front. Ecol. Evol. 2020, 8, 1-18. [CrossRef]

22. Eghdami, H.; Azhdari, G.; Lebailly, P.; Azadi, H. Impact of Land Use Changes on Soil and Vegetation Characteristics in Fereydan, Iran. Agriculture 2019, 9, 58. [CrossRef]

23. Mahmoud, A.E.M.; Abbas, M.S.; Cieslak, A.; Szumacher-Strabel, M. Evaluation of chemical composition and In Vitro dry and organic matter digestibility of some forage plant species derived from Egyptian rangelands. J. Anim. Plant Sci. 2017, 27, 1573-1581.

24. Mseddi, K.; Alghamdi, A.; Abdelgadir, M.; Sharawy, S.; Chaieb, M.; Miller, T. Phytodiversity distribution in relation to altitudinal gradient in Salma Mountains-Saudi Arabia. Glob. Ecol. Conserv. 2021, 27, e01525. [CrossRef] 
25. Li, L.; Chen, J.; Han, X.; Zhang, W.; Shao, C. Grassland Ecosystems of China: A Synthesis and Resume; Springer Nature: Singapore, 2020; Volume 583. [CrossRef]

26. Karami, P.; Bandak, I.; Karaji, M.G. Comparing the effects of continuous grazing and long term exclosure on floristic composition and plant diversity in rangeland ecosystems of Saral, Iran. Int. J. Environ. Sci. Technol. 2019, 16, 7769-7776. [CrossRef]

27. Sasaki, T.; Okayasu, T.; Jamsran, U.; Takeuchi, K. Threshold changes in vegetation along a grazing gradient in Mongolian rangelands. J. Ecol. 2008, 96, 145-154. [CrossRef]

28. Du Toit, M.; Du Preez, C.; Cilliers, S. Plant diversity and conservation value of wetlands along a rural-urban gradient. Bothalia 2021, 51, 1-18. [CrossRef]

29. Ghafari, S.; Ghorbani, A.; Moameri, M.; Mostafazadeh, R.; Bidarlord, M.; Kakehmami, A. Floristic Diversity and Distribution Patterns Along an Elevational Gradient in the Northern Part of the Ardabil Province Rangelands, Iran. Mt. Res. Dev. 2020, 40, R37-R47. [CrossRef]

30. Rawat, D.S.; Bagri, A.S.; Parveen, M.; Nautiyal, M.; Tiwari, P.; Tiwari, J. Pattern of species richness and floristic spectrum along the elevation gradient: A case study from western Himalaya, India. Acta Ecol. Sin. 2021, 41, 545-551. [CrossRef]

31. Miller, R.I.; Wiegert, R.G. Documenting Cmpleteness, Species-Area Relations, and the Species-Abundance Distribution of a Regional Flora. Ecology 1989, 70, 16-22. [CrossRef]

32. Margalef, R. Information theory in biology. Gen. Syst. Yearb. 1958, 3, 36-71.

33. Shannon, C.L.; Weaver, W. The Mathematical Theory of Communication; University of Illinois Press: Urbana, IL, USA, 1963.

34. Buzas, M.A.; Gibson, T.G. Species Diversity: Benthonic Foraminifera in Western North Atlantic. Science 1969, 163, 72-75. [CrossRef]

35. Simpson, E.H. Measurement of diversity. Nature 1949, 163, 668. [CrossRef]

36. Krebs, C.J.; Berteaux, D. Problems and pitfalls in relating climate variability to population dynamics. Climate Res. 2006, 32, 143-149. [CrossRef]

37. Avolio, M.L.; Carroll, I.T.; Collins, S.L.; Houseman, G.R.; Hallett, L.M.; Isbell, F.; Koerner, S.E.; Komatsu, K.J.; Smith, M.D.; Wilcox, K.R. A comprehensive approach to analyzing community dynamics using rank abundance curves. Ecosphere 2019, 10 , e02881. [CrossRef]

38. Gart, J.J.; Siegel, A.F.; German, R.Z. Rarefaction and Taxonomic Diversity. Biometrics 1982, 38, 235. [CrossRef]

39. Magurran, A.E. Measuring Biological Diversity; John Wiley \& Sons: Hoboken, NJ, USA, 2013.

40. Salama, F.; El-Ghani, M.A.; Gadallah, M.; El-Naggar, S.; Amro, A. Diversity and responses of plant functional groups to soil variables in the arid desert landscape of southern Egypt. J. Biodivers. Ecol. Sci. 2015, 5, 24-39.

41. Abdi, M.; Afsharzadeh, S. An analysis of vegetation and species diversity patterns in sand dune and gravel desert ecosystem. Bot. Sci. 2016, 94, 499-511. [CrossRef]

42. Abdelaal, M. Current status of the floristic composition in Wadi Hagul, Northwest Suez Gulf, Egypt. Rend. Lincei 2017, 28, 81-92. [CrossRef]

43. Angassa, A. Effects of grazing intensity and bush encroachment on herbaceous species and rangeland condition in Southern Ethiopia. Land Degrad. Dev. 2014, 25, 438-451. [CrossRef]

44. Wu, G.-L.; Du, G.-Z.; Liu, Z.-H.; Thirgood, S. Effect of fencing and grazing on a Kobresia-dominated meadow in the QinghaiTibetan Plateau. Plant Soil 2009, 319, 115-126. [CrossRef]

45. Egeru, A.; Wasonga, O.; MacOpiyo, L.; Mburu, J.; Tabuti, J.R.S.; Majaliwa, M.G.J. Piospheric influence on forage species composition and abundance in semi-arid Karamoja sub-region, Uganda. Pastoralism 2015, 5, 343. [CrossRef]

46. Hoshino, A.; Yoshihara, Y.; Sasaki, T.; Okayasu, T.; Jamsran, U.; Okuro, T.; Takeuchi, K. Comparison of vegetation changes along grazing gradients with different numbers of livestock. J. Arid Environ. 2009, 73, 687-690. [CrossRef]

47. Mudongo, E.I.; Fynn, R.W.; Bonyongo, M.C. Role of Herbivore Impact and Subsequent Timing and Extent of Recovery Periods in Rangelands. Rangel. Ecol. Manag. 2016, 69, 327-333. [CrossRef]

48. Atroosh, K.B.; Ahmed, G.A.-K.; Lardi, O.S.; Eissa, Z.A.; Belgacem, A.O. Yield and Irrigation Water Productivity of Three Varieties of Buffel Grass (Cenchrus ciliaris L.) in the Southern Coastal Plains of Yemen. J. Agric. Sci. 2017, 10, 114. [CrossRef]

49. Al-Dakheel, A.J.; Hussain, M.I.; Rahman, A.Q.M.A. Impact of irrigation water salinity on agronomical and quality attributes of Cenchrus ciliaris L. accessions. Agric. Water Manag. 2015, 159, 148-154. [CrossRef]

50. Anderson, P.; Hoffman, M. The impacts of sustained heavy grazing on plant diversity and composition in lowland and upland habitats across the Kamiesberg mountain range in the Succulent Karoo, South Africa. J. Arid Environ. 2007, 70, 686-700. [CrossRef]

51. Landsberg, J.; James, C.D.; Morton, S.R.; Müller, W.J.; Stol, J. Abundance and composition of plant species along grazing gradients in Australian rangelands. J. Appl. Ecol. 2003, 40, 1008-1024. [CrossRef]

52. Todd, S.W. Gradients in vegetation cover, structure and species richness of Nama-Karoo shrublands in relation to distance from livestock watering points. J. Appl. Ecol. 2006, 43, 293-304. [CrossRef]

53. Mureithi, S.M.; Verdoodt, A.; Gachene, C.K.K.; Njoka, J.T.; Wasonga, O.; De Neve, S.; Meyerhoff, E.; Van Ranst, E. Impact of enclosure management on soil properties and microbial biomass in a restored semi-arid rangeland, Kenya. J. Arid Land 2014, 6 , 561-570. [CrossRef]

54. Inman, E.N.; Hobbs, R.J.; Tsvuura, Z.; Valentine, L.C. Current vegetation structure and composition of woody species in community-derived categories of land degradation in a semiarid rangeland in Kunene region, Namibia. Land Degrad. Dev. 2020, 31, 2996-3013. [CrossRef] 
55. Hendricks, H.H.; Bond, W.; Midgley, J.J.; Novellie, P.A. Plant species richness and composition a long livestock grazing intensity gradients in a Namaqualand (South Africa) protected area. Plant Ecol. 2005, 176, 19-33. [CrossRef]

56. Van der Waal, C.; Kool, A.; Meijer, S.S.; Kohi, E.; Heitkönig, I.M.; de Boer, W.F.; van Langevelde, F.; Grant, R.C.; Peel, M.J.; Slotow, R.; et al. Large herbivores may alter vegetation structure of semi-arid savannas through soil nutrient mediation. Oecologia 2011, 165, 1095-1107. [CrossRef]

57. Akapali, M.; Ansah, T.; Abdul-Rahman, I.I.; Alenyorege, B.; Baatuuwie, B.N. Seasonal changes in pasture biomass and grazing behaviour of cattle in the Guinea Savanna agroecological zone of Ghana. Afr. J. Range Forage Sci. 2018, 35, 101-108. [CrossRef]

58. Gotelli, N.J.; Colwell, R.K. Quantifying biodiversity: Procedures and pitfalls in the measurement and comparison of species richness. Ecol. Lett. 2001, 4, 379-391. [CrossRef] 